\title{
Granular cell tumour (Abrikossoff's tumour) of the tongue
}

\author{
Pedro Nuno Dias Ferraz (1) , ${ }^{1}$ Vladislav Danu, ${ }^{1}$ Rui Almeida, ${ }^{2}$ José Figueiredo ${ }^{1}$
}

${ }^{1}$ Stomatology, Centro Hospitalar e Universitário de Coimbra EPE, Coimbra, Portugal

${ }^{2}$ Pathology, Centro Hospitalar e Universitário de Coimbra EPE, Coimbra, Portugal

\section{Correspondence to} Dr Pedro Nuno Dias Ferraz; pedrodferraz@icloud.com

Accepted 26 June 2020

\section{DESCRIPTION}

We report a case of a 43-year-old female patient, referred to the stomatology consultation by her general and family medicine doctor, for the observation of a 1-year-old lesion on the tongue. The patient reported that the lesion was painless and slow growing.

She had no relevant personal history or relevant usual medication. There were no smoking and/or alcohol habits.

Physical examination revealed a firm, wellcircumscribed whitish lesion of about $1.5 \mathrm{~cm}$ in diameter, located at the posterior limit of the middle third of the dorsum of the tongue (figure 1).

Thus, an incisional biopsy was performed, whose histological study revealed the diagnosis of granular cell tumour (GCT) in the dorsal region of the tongue.

Given the result, we opted to perform an excisional biopsy under local anaesthesia (figure 2). The macroscopic sample had the dimensions of $1.5 \times 0.9 \times 0.4 \mathrm{~cm}$, with whitish surface. Its anatomopathological study confirmed the diagnosis of GCT in the dorsal region of the tongue, and it also reported a submucosal lesion, consisting of proliferation of polygonal cells with large clarified granular cytoplasm Periodic acid-Schiff (PAS+), and with central, oval and monotonous nucleus. There was pseudoepitheliomatous hyperplasia $(\mathrm{PH})$ of the lining. Regarding immunohistochemical analysis, the cells had marked and diffuse immunostaining for S100 protein (figures 3-5).

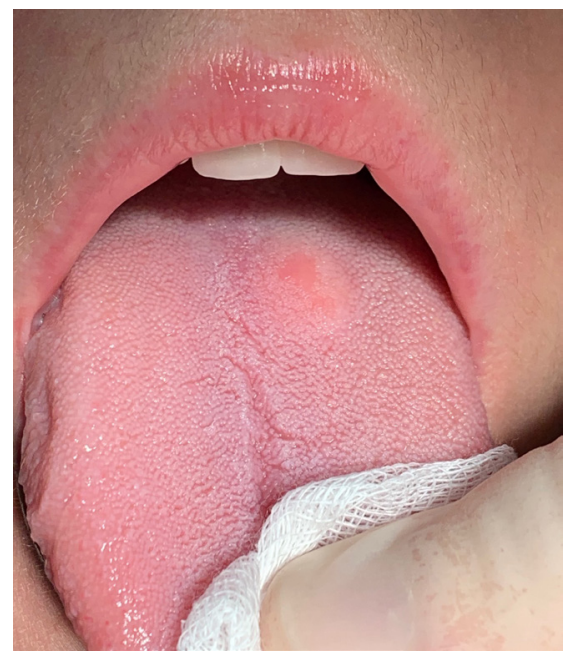

Figure 1 Image of lesion.

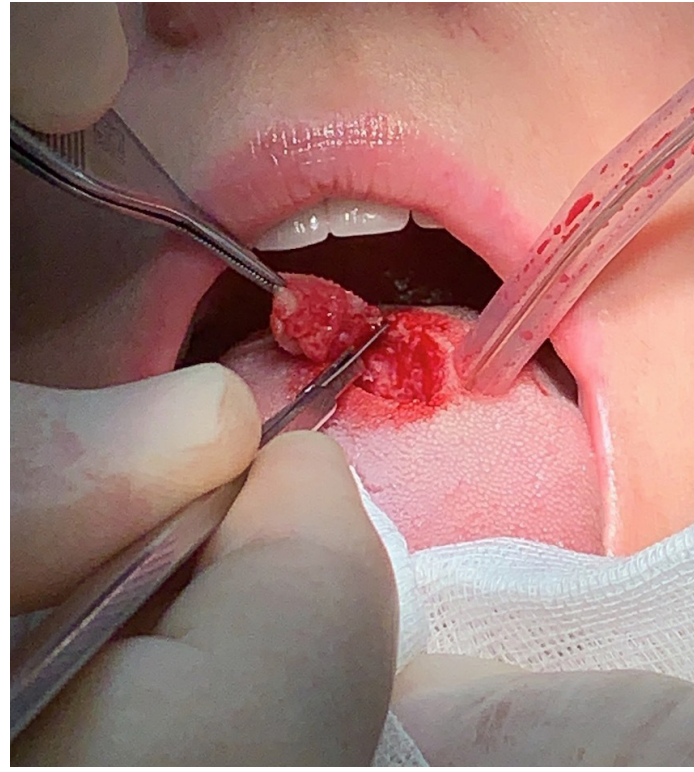

Figure 2 Excisional biopsy.

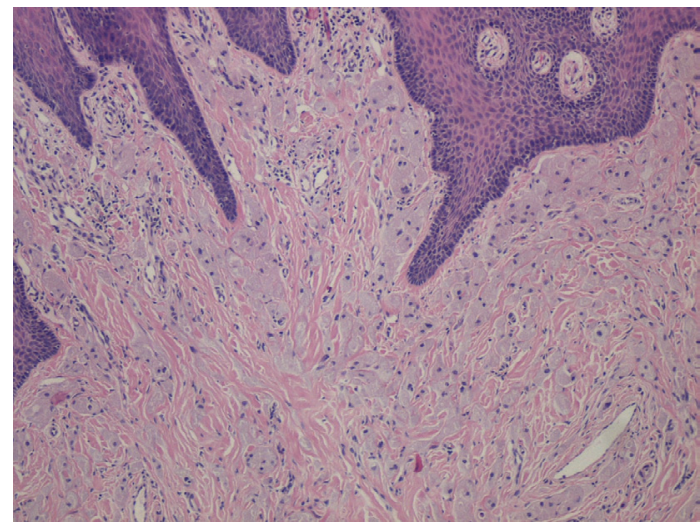

Figure $3 H \& E(100 x$ and $400 x)$ : poorly defined lesion composed of sheets separated by collagenous band. Cells are polygonal or spindle, with abundant and granular eosinophilic cytoplasm, and small nuclei.

In the postoperative period, the patient evolved without intercurrences. There are no signs of recurrence of the lesion 1 year after the surgery.

GCT is an uncommon benign neoplasm that still reveals some controversial aspects. GCT can commonly occur in the oral cavity, particularly in the anterior part of the tongue. ${ }^{1}$ Also known as Abrikossoff's tumour, is characteristically asymptomatic, with slow growth, and is often accidentally detected. It is characterised by the presence of a small, well-defined, submucosal nodular mass, about $1-3 \mathrm{~cm}$ in size, of firm consistency and usually 


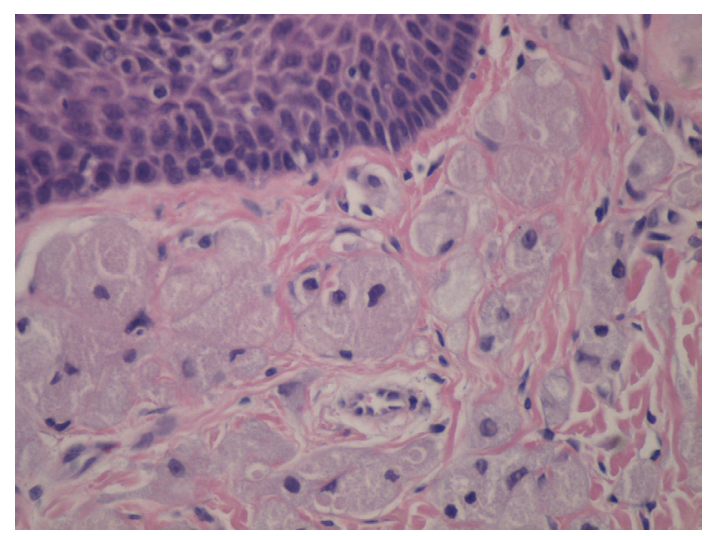

Figure $4 \quad H \& E(100 x$ and 400x): poorly defined lesion composed of sheets separated by collagenous band. Cells are polygonal or spindle, with abundant and granular eosinophilic cytoplasm, and small nuclei.

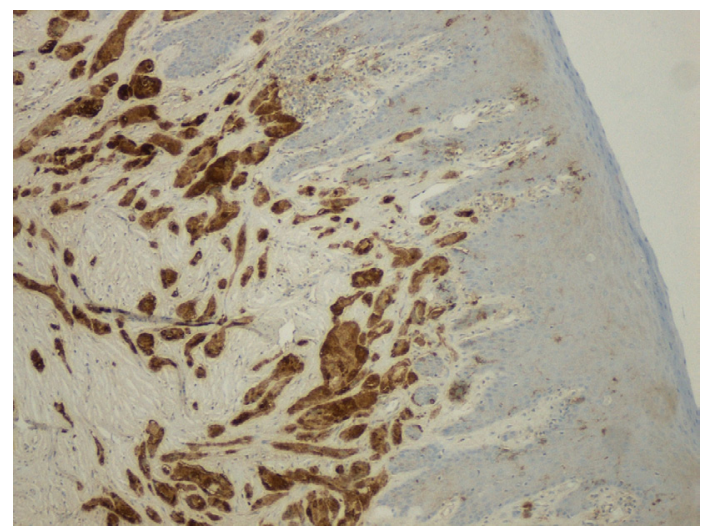

Figure 5 Immunohistochemistry $\$ 100$ (100x): lesional cells expressing diffuse positivity for $\mathrm{S} 100$ protein.

covered by intact mucosa. ${ }^{2}$ The estimated incidence of oral GCT is approximately 1:1.000 000 population per year. There are no distinct geographical or racial differences. Apparently, there is no explanation for the well-known female predilection. ${ }^{2}$ The diagnostic hypothesis was fibroma, lipoma, neurofibroma, schwannoma and GCT. Neurofibroma and schwannoma should be the main considerations for tongue injuries. Lipoma and other benign mesenchymal neoplasms may present intraorally as asymptomatic nodules similar to the GCT. Traumatic fibroma is a common reactive lesion that should be included in the differential diagnosis. ${ }^{3}$

\section{Learning points}

- The importance of the relationship between clinical and histological and immunohistochemical aspects, all of which are essential to establish the correct diagnosis of granular cell tumour (GCT).

- Immunohistochemical analysis makes it possible to deepen the knowledge of the aetiopathogenesis of GCT as well as the possible association with other tumours.

- It is possible to perform a correct medical-surgical approach to this type of injury.

The persistence of the presence of S100 protein (pathognomonic marker for peripheral nerve sheath tumours) associated with anatomical similarities with peripheral nerve fibres supports this theory. In this case, the immunohistochemical analysis showed a positive chain for protein S100, which is considered sufficient for the proposed diagnosis ${ }^{4}$ (figure 5). The phenomenon of $\mathrm{PH}$ is uncommon in other benign connective tissue tumours but is frequent in GCT. ${ }^{1}$

Although aggressive and malignant variants of this neoplasm have been described, most of the GCTs are benign. Complete excision of the lesion may not be always possible due to absence of capsule. Therefore, it is advisable to perform an excision with enough safety margin to reduce the probability of recurrence.

Acknowledgements I would like to thank Dr José Paiva Amorim for his support.

Contributors PNDF: wrote the manuscript. VD: contribution in the acquisition of data. RA: made his contribution in his help of anatomopathological and histological analysis. JF: made his contribution in conduct and reporting the case.

Funding The authors have not declared a specific grant for this research from any funding agency in the public, commercial or not-for-profit sectors.

Competing interests None declared.

Patient consent for publication Obtained.

Provenance and peer review Not commissioned; externally peer reviewed.

ORCID iD

Pedro Nuno Dias Ferraz http://orcid.org/0000-0003-0753-1608

\section{REFERENCES}

1 Freitas J, Mata L, et al. Tumor de células granulares intra-orais: apresentação de dois casos clínicos. Rev Port Estomatol Med Dentária e Cir Maxilofac 2019;60:4-9.

2 van de Loo S, Thunnissen E, Postmus P, et al. Granular cell tumor of the oral cavity; a case series including a case of metachronous occurrence in the tongue and the lung. Med Oral Patol Oral Cir Bucal 2015;20:e30-3.

3 Serpa MS, Costa-Neto H, de Oliveira PT, et al. Granular cell tumor in two oral anatomic sites. Eur Arch Otorhinolaryngol 2016;273:3439-41.

4 Ferreira JCB, Oton-Leite AF, Guidi R, et al. Granular cell tumor mimicking a squamous cell carcinoma of the tongue: a case report. BMC Res Notes 2017;10:1-6.

Copyright 2020 BMJ Publishing Group. All rights reserved. For permission to reuse any of this content visit

https://www.bmj.com/company/products-services/rights-and-licensing/permissions/

BMJ Case Report Fellows may re-use this article for personal use and teaching without any further permission.

Become a Fellow of BMJ Case Reports today and you can:

- Submit as many cases as you like

- Enjoy fast sympathetic peer review and rapid publication of accepted articles

- Access all the published articles

- Re-use any of the published material for personal use and teaching without further permission

Customer Service

If you have any further queries about your subscription, please contact our customer services team on +44 (0) 2071111105 or via email at support@bmj.com.

Visit casereports.bmj.com for more articles like this and to become a Fellow 